\title{
Integration of the Energy and Building Technologies
}

\author{
Consiglia Mocerino \\ Already contract professor in the Faculty of Architecture, Sapienza University of Rome-Miur, Rome, Italy
}

\begin{abstract}
The performance of each type of building must meet all the needs and requests of new real estate markets. In fact, in the excellent architectures, the user can manage, with autonomy and flexibility, each system and product, according to the new energy and building technologies too. The main objective is the social and environmental sustainability with the reduction of fossil fuels and the greenhouse gas effect, pushing the use of renewable energies, in a new trend of land regeneration with sustainable buildings and settlement recovery. The energy crisis, mainly generated by the climate change, the air pollution, with consequent extinction of the species, reduction of the land and the work, the degradation and the environmental and seismic risk, focuses on the security and quality of construction systems, integrated use of clean resources. The methodologies aimed at integrating of energy-efficient and innovative building technologies in architecture, from design to management, to produce electric and thermal energy with active and passive properties, for a high-performance habitat. Therefore, the use of solar photovoltaic in the buildings, BIPV (Building Integrated Photovoltaic) with high-performance glass vision, efficient systems, intelligent materials, is integrated in architectures with the use of innovative construction systems, finally, technology of OPV (Organic Photovoltaic), multi-junction cells, the dye sensitized solar cells in the solid state, etc., and adoption of storage systems.
\end{abstract}

Key words: Building, technology, BIPV, photovoltaic, nanostrucure, energy, sustainability, urban.

\section{Introduction}

"Keep it on the ground. Fossil fuel divestment campaign" reported by this article in The Guardian in March, 2015 [1] highlights the global eco use renewable resources and sustainability of the planet, through a campaign of disinvestment of fossil fuels. Although oil companies have reacted through a carbon tax to freezing extraction of fossil fuels within the next five years, the trend is to encourage investment programs for clean energy and decarburization. The energy crisis, generated mainly by climate change and air pollution, affected by economic progress of new phases in the evolution of systems and innovative clean technologies aimed at sustainable development. In fact, with European energy and environmental strategies, objectives are established, criteria and tools for use of RES (Renewable Energy Sources) (Directive 2009/28/EC) for a competitive green

Corresponding author: Consiglia Mocerino, Arch. Ph.D., research fields: technological innovation, sustainable and intelligent systems, requalification of buildings and renewable energy. economy and efficient-COM (2010) 2020. The main purpose of the EEPR (European Energy Programme for Recovery), is energy efficiency up to $20 \%$, reducing carbon $20 \% \sim 30 \%$, and adoption of renewable energy to $20 \%$ of end-use power consumption, heat and transport, increase of $75 \%$ and investment of 3\% of GDP (gross domestic product) employment rate, research and economic development. Also technologies for CCS (Carbon Capture and Storage) - (Directive 2009/31/EC), while the Energy Roadmap 2050-COM (2011), aims mainly to Europe without carbon up to $80 \% \sim 90 \%$ with innovative technologies that manage the clean and intelligent energy, through an SET (Strategic Energy Technology) plan for all member states. In fact, in international and global policies to fight climate change, as the COP 21 in Paris, they indicate energy use transformations strategies aimed to renewable resources (Its implementing regulation is defined in December, 2018 as established by the COP 22 in Marrakech). They stand out with rates reaching over $90 \%$, as in Norway and Costa Rica, and others that extend mainly 
from Central America, Europe to Asia. These initiatives with investment policies, such as the Green Climate Fund of the United Nations Framework Convention [2], have increased by more causes impact on the globe, the concentration of $\mathrm{CO}_{2}$ with overheating, erosion and reducing soil erosion witnessing, in many cases to the collapse of the Greenland ice sheet, such as the recent disappearance in the pacific ocean, northeast of Australia, five of uninhabited islands in the Solomon Islands whose government has participated in the same agreement in Paris in 2015. In addition, there is the destruction of Australia's Great Barrier Reef, with the exodus of populations and lack of jobs. The pollution levels recorded to date is about $400 \mathrm{ppm}$, and we can reach $2{ }^{\circ} \mathrm{C}$.

The trends are adopting renewable energy technologies that project to the development and creation of market distinguishing itself mainly in the construction and transport sectors, as well as incentive policies and global investment. A recent study by TCEP (Tracking Clean Energy Progress) by IEA (International Energy Agency), divided into 18 sections, records results, by monitoring, in different countries, sectors and sub sectors, the possible evolution of the adoption of technologies clean, of measures for the reduction of emissions, energy saving. These, through predetermined parameters, are monitored to see if you can reach intermediate goals of 2DS for the 2025 .

And to reach, in 2050, the final objectives of application for clean technologies, low-carbon, such as the implementation tool for saving energy and reducing $\mathrm{CO}_{2}$, towards the sustainable development in the construction sector, together with the production of energy and transport, in order to limit to $50 \%$ the increase in the planet's temperature, the only building sector recorded a percentage of $17 \%$ compared to the industries by almost double, while the percentage with less energy. Therefore, it needs, in light of what occurs in the world, a secure energy model based on economies of scale and above all the instrument of decarburization of energy usage with energy efficiency from renewable sources, and a territory run by a smart grid network including infrastructure of the third industrial revolution. Indeed, the models are designed at various scales including the Chinese one of the "Internet of energy" based on the UHV (Ultra High Voltage System) that, through a network of intelligent grids, connects all the continents for the exchange of energy in high percentages from a renewable source.

Consequently, the housing market requires a regeneration performance building for the construction of new buildings and redevelopment of built clean energy systems and sustainable accumulation. In fact, as the buildings indicate a power consumption that exceeds $1 / 3$ of the world, with high levels of carbon dioxide emission indexes $\left(\mathrm{CO}_{2}\right)$, they will identify the strategic models to reduce emissions, the final consumption of energy and transform resources in the most secure and renewable. So, within this scenario, it is important to evaluate all of the energy consumption of buildings, in different types, to finalize the well efficiency, through the integration of energy and building technologies and smart, sustainable products, to low impact, low-cost. The only buildings could consume energy up to $50 \%$ more in 2050 , compared 2013, according to IEA-ETP 2016 (Fig. 1), for which it needs a new culture of building with building systems that interact with energy efficient technologies, to reduce this increase.

So they propose operational and organizational models of a new building process, in which the application of energy resources indicate emerging strategies for integrated models of architectural design and installation, high performance, first and foremost, for the satisfaction of user needs and for better light comfort and thermal/acoustic and housing quality. To the design, practices relate the complex regeneration procedures and urban and land redevelopment, pointing to efficient and intelligent infrastructure, 


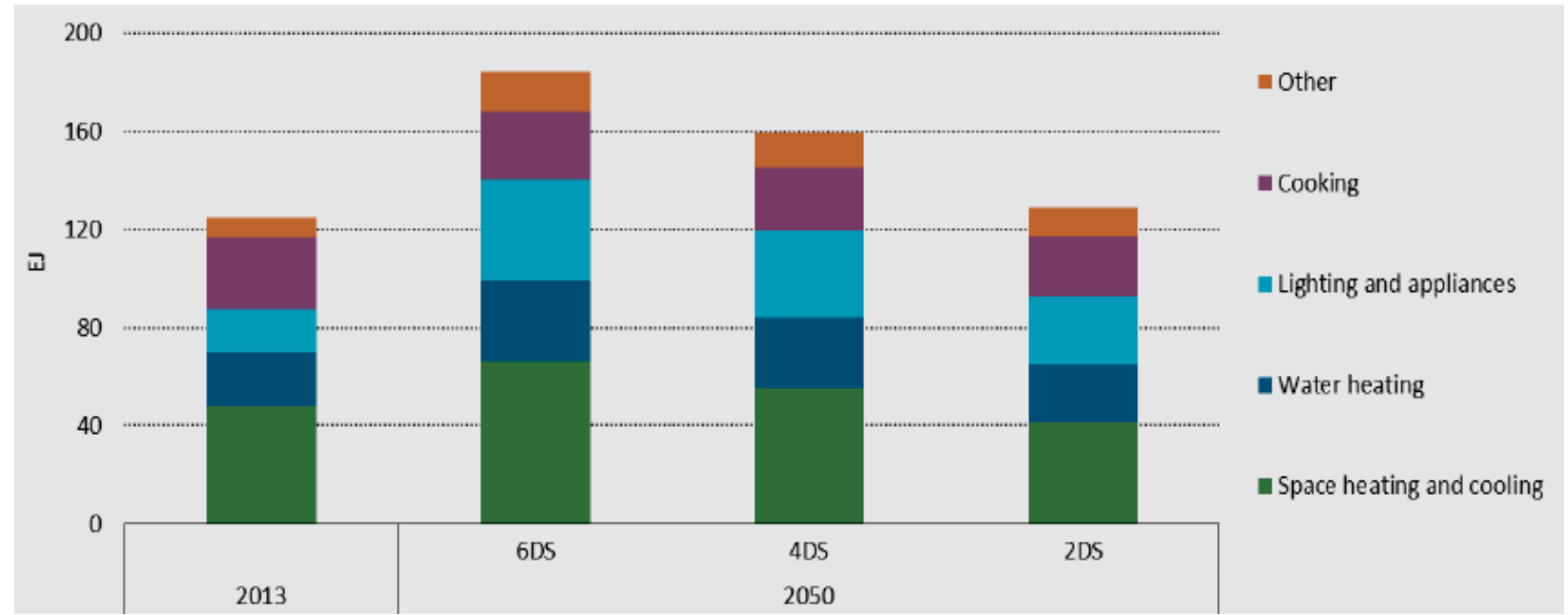

Fig. 1 End-use energy consumption in buildings, until 2050. IEA.ETP 2016. Source: Ref. [3].

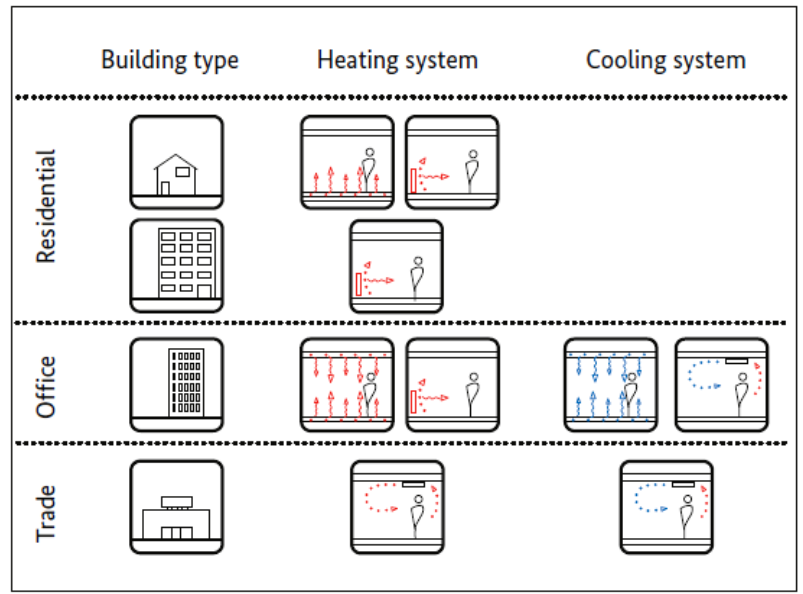

Fig. 2 Building typologies and related services. Source: Ref. [4].

smart networks in a network. To do this is to emphasize the need to establish certain codes for the construction that they are respected in the different countries and characterized by morphological, hydrological, climatic, solar, etc. characteristics. In fact, the integration, also aimed at the security of the building in addition to aesthetic parameters, is highlighted by the use of environmentally friendly materials, including certified wood, glass, etc. Codes that involve the entire know-how and which aim to values of global standards, with a view to energy efficiency in buildings, both for new buildings and the built and social and environmental sustainability.

\section{Building and Energy Systems}

\subsection{The Efficiency Integration}

The constructive and technological systems of the building are connected to an evolution of the integrated design with plant systems and markets, that improve the performance of the building contextualized in aesthetic/qualitative and energy terms. The elements of the technological and environmental typological system in different building types (Fig. 2) are integrated in service systems and renewable sources of energy, which tend to limit those of source of fossil fuels.

So studies and sector research are spread across the world, and among them there is the WEM (World Energy Model) 2015 IEA, a simulation model for the use of energy technology building. The energy efficiency of the different facilities in the building also depends on the type of installation of the different systems, according to numerous studies and those conducted in the TUM (Technische Universität München) (Fig. 3 ). So plant requirements integrated into a design process model follows an orientation process of the lot, with analysis of the meteorological aspects, where the new and existing building is identified. Following the energy audit, the adoption of methodologies, tools, policies, reaching strategies, and 


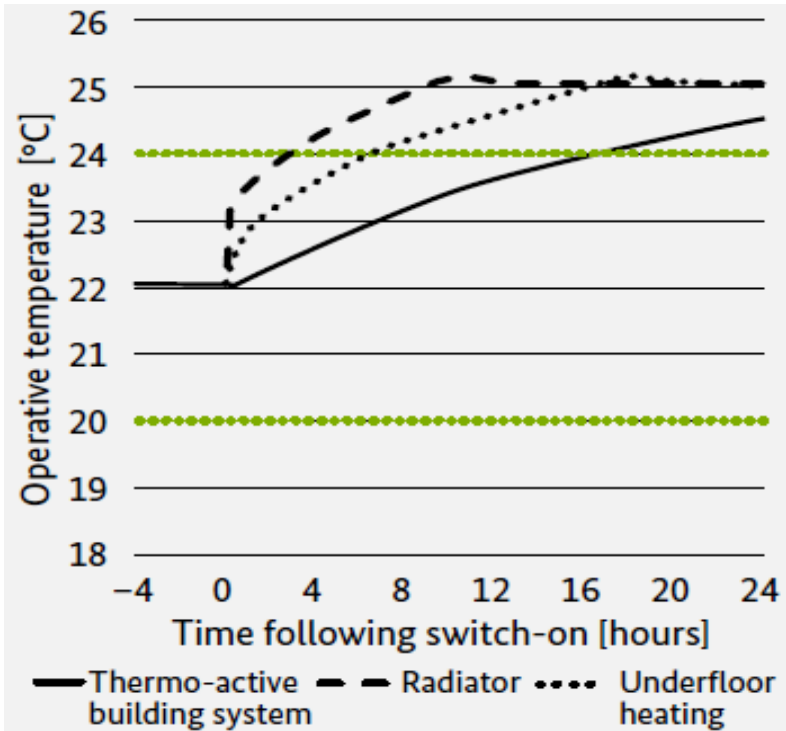

Fig. 3 Simulation of heat transmission as a function of internal heating systems installation.

Source: Ref. [4].

finally the design with implementation and management aimed at the low impact objectives, the environment and the health of users. Also, they settle needs - performance parameters for the environmental comfort, with further use of energy systems that mostly use solar energy, along with all other renewable sources.

In this evolutionary process, we distinguish the KETs (Key Enabling Technologies) and innovative building materials with a tendency towards nanotechnology (both identified in Horizon 2020 EC program) for flexibility, high energy efficiency and meeting the acoustic insulation requirements. In addition to thermal acoustic wellbeing, air tightness, reduction of pollution emissions and meeting the minimum values of transmittance of building envelopes, the KETs technologies [5] or enablers are identified in process models through the synergistic integration of cross-cutting KETs. They are identified in the development of micro electronics and electromechanical devices of the industrial sector, nanotechnology, photonics, advanced services and AMS (Advanced Manufacturing System).

So an integrated design of innovative technological systems, equipment, materials and components aimed at satisfying of needs/performance with requirements of ultra thin, biocompatible, durable, resilient, reversible dry systems. The energy factor is in a dialectical relationship in the various architectural configurations. All over the Italian territory, they are distributed about 850 thousand electrical and thermal installations plants from renewable sources that indicate an overall increase in energy from $5.3 \%$ to $17 \%$, recording in ten years an increase from 51.9 TWh to $109 \mathrm{TWh}$ and they prevent reduction of over 14.8 Mln tons of carbon dioxide in the atmosphere. While showing the presence of 13 active coal plants that cover $13.5 \%$, according to the WWF (World Wide Fund), the demand for electrical use, occurring 39.4 Mln tons of $\mathrm{CO}_{2}$ with impact on the environment, human health and the environment that lead to the GD (Distributed Generation) increase. A decentralized production system in different points of the territory is connected, through low-voltage generators, directly to the electrical distribution network, so are biomass generators, photovoltaics, geothermal energy with heat pumps with COP (Coefficients of Performance) higher than the lower difference between the well and thermal source. Besides wind power, high efficiency cogeneration, trigeneration, district heating, hybrid systems of solar and wind energy (solar wind energy in Arizona, with gross production up to 1,250 megawatts and without inverter), etc., to reduce power consumption and carbon dioxide emissions with the integration of energy efficient technologies and eco construction of the building. Thus, it points the optimization of integrated envelopes, high-performance components and sensitive materials to the incidence of passive solar energy, energy efficient technologies and eco construction of in the summer and winter periods. They also become producers of clean energy, both for the building and for the city, and assume the function of catalysts for energy flows between the internal environment and the context.

In fact, in architectural design, an evolutionary 
method, in which the BIM (Building Information Modelling), building automation, with devices, sensors and actuators, ICT (Information and Communication Technologies) interact in a building meta-system, develops an architecture meta, structure and systems with greater control over consumption energy and reduction of $\mathrm{CO}_{2}$. They, through the building, space and business management, are projected in the design and construction management for the optimization of the new construction process. In it are highlighted interactions with climate change affecting in buildings and their vulnerability, both new and existing [6], and whose new constructive process that the redevelopment are highlighted also by quality certifications, according to world standards. In fact, they adopt efficient building technologies as developing double- or triple-glazed skin envelopes, on different types of glass, transparent or opaque (Fig. 4): (1) PV module; (2) insulating core; (3) backing sheet; (4) mullion; (5) transom; (6) clamping bar for curtain wall, solar panels of 3rd generation (organic, emerging thin films, amorphous silicon, etc.), integrated, ventilated wall with PV (Fig. 5), BIPV (Building Integrated Photovoltaic), with innovative photovoltaic cells. Just in a recent research, that improves the performance of multi-junction photovoltaic cells, comes from MIT (Massachusetts Institute of Technology) with the Masdar Institute of Science and Technology [7], with a "step cell" of only two layers: the lower silicon with upper gallium phosphide (GaAsP), overlapping and staggered as a step.
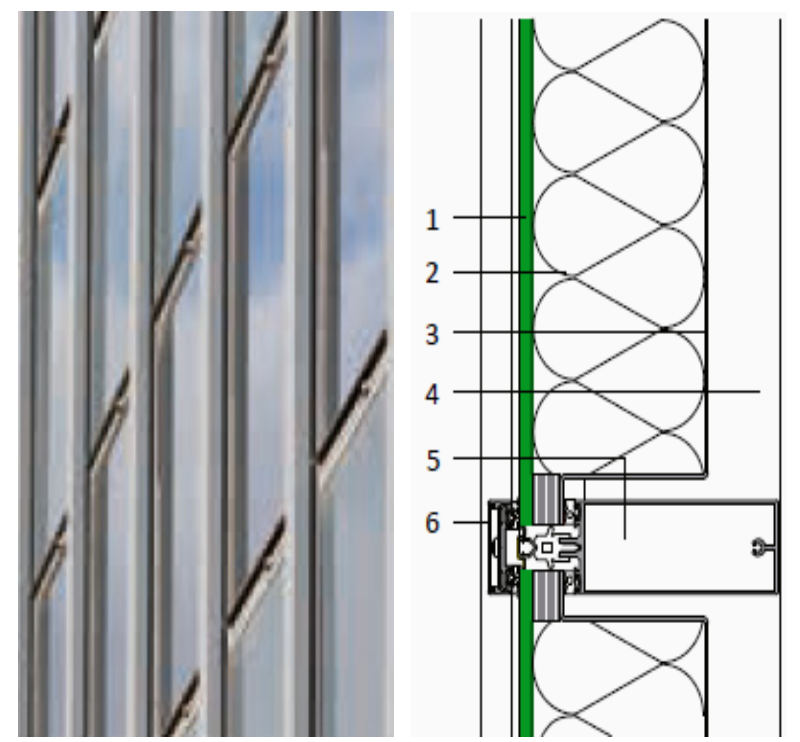

Fig. 4 Opaque curtain wall (as electricity generator) on metal mullion and transom structure: integration of constructive component of Sprandel Glass and PV module. Source: Ref. [8].

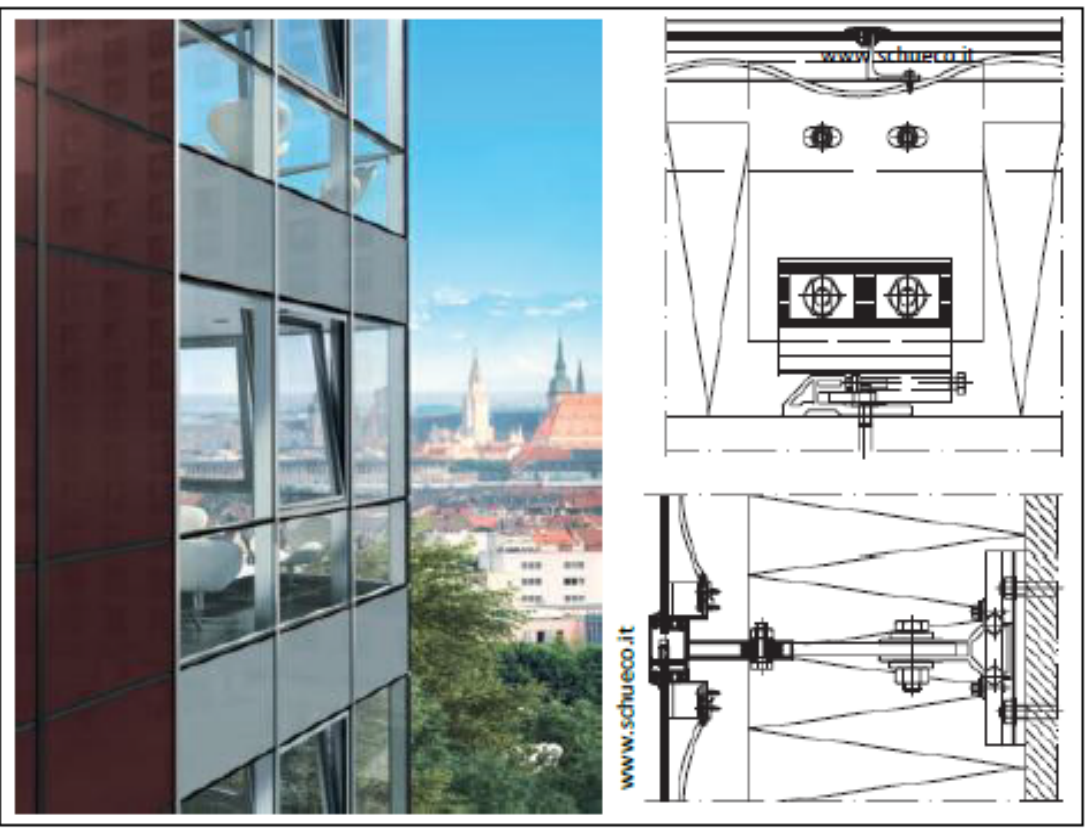

Fig. 5 Ventilated facade with transparent glass and aluminum—Modules Prosol, Schüco.

Source: Ref. [9]. 
They may reach a theoretical efficiency of over $50 \%$ at a lower cost compared to others with similar characteristics and capture high-energy photons from light blue, yellow and green, while the silicon absorbs low energy photons from the red light. Equally innovative are the solar PVs in film solar cells CIGS (Copper Indium Gallium Selenide) and ETFE (polytetrafluoroethylene) films as efficient integration in architecture, especially on roof and on the facades aimed at the production of electrical energy. But the surplus energy produced by the photovoltaic systems in the building, etc., is transmitted in the urban/territorial network and is based on connected-on grid digital technologies, function of the large expansion of the distributed generation of electrical energy, in which different storage systems are required, so are methods of application of efficient energy technology systems from RES for the production of electricity and thermal energy in the building system.

It is realized with distributed intelligence in which the system integrator coordinates and integrates all energy systems and building services including BEMS (Building Energy Management System). These PCs (Process Control Systems) have the control, management and intelligent monitoring of HVAC (Heating Ventilation Air Conditioning) systems, lighting, ventilation, security, fire, etc., but above all, improve the energy performance of buildings.

If they are connected through wireless networks to IoT, the user intervenes in real time on the systems, including through the monitoring and management directly in the building that in remotely, through apps on the tablet and iPhone. With energy and thermal transmittance performance, indices established in Italy, respectively, by Dlgs.192/2005 and Dlgs.311/2006 identify the energy requirements of buildings. These, together with the Directive 2010/31/EU (EPBD) on the improvement of energy efficiency and the Dir 2012/27/EU on energy efficiency, can be divided into further minimum requirements that aim at upgrading buildings and NZEB (artt.2.9 of the EPBD) - to nearly zero energy buildings. On the improvement of energy IEA (International Energy Agency) report in 2015, Italy is the first in the world for the use of photovoltaics with the $8.0 \%$ of the electricity supply required, with $7.4 \%$ in Greece and $7.1 \%$ Germany, with a worldwide total contribution of $1.3 \%$, from IEA and TERNA (Trasmissione Elettrica Rete Nazionale) data. While there is a global market of over $50 \mathrm{GW}$ compared to $11.4 \mathrm{GW}$ of about ten years ago, with the US and China in expansion and also the countries developing as the Asia region, so are the methods of application of efficient energy technology systems from RES for the production of electricity and thermal energy in the building system.

By Law 90 of August 3, 2013, the transposition takes place in Italy through the "Decree of the minimum" of October 1, 2015 whose applications follow a different timing startup but with the same maturities, in the various Italian regions. Just in this decree, it is reaffirmed the use of renewable sources produced "in situ", so are new models in a multidisciplinary contribution of the designers skills through qualitative methodologies of intervention for the integrated project, IED (Integrated Energy Design) [10] of innovative systems and system components. They are aiming at the construction of efficient buildings that combine different figures in the team of designers with architects, engineers, sociologists, geologists, companies, manufacturing companies, energy managers, ESCOs (Energy Service Company), commission, etc., in a performance/functional balance of the spaces with the aesthetics, technique and the services of the building.

\subsection{The Technological Typologies}

The building is considered throughout the life cycle, while the integrated design process of the architectural/plant and energy design. So evolutionary method of sustainable building concept/system that interacts with the contest, the environment and the 
user also managed remotely through digital devices connected to BIoT (Building Internet of Things).

The organizational process model for an advanced integrated design of a new operating model, in which the LCA (Life Cycle Assessment) during its articulation in various stages of construction, assesses the impact of the building is that of materials on the environment by defining the environmental performance of the building structure, according to ISO 14040 standards. In Italy, was introduced the system EPD (Environmental Product Declaration) that, among its energetic principles, defines environmental sustainability indicators of $\mathrm{CO}_{2}$, resource efficiency and the water footprint. So interoperability with energy/environmental resources systems and the user, an eco integrated project, in which each phase of progress controls and audits are associated, to re-evaluate whether or not the effects of different design choices. Thus, the trend is clearly established that the Green BIM design that integrates the Building Automation and BIoT on wireless systems, with ICT technologies will finalize the construction of Sustainable buildings, energy-efficient and intelligent.

In fact, they develop models of efficient envelopes with different distributions and layout intended for residences, offices and tertiary to open space, etc., highlighting solar energy which is produced by electromagnetic energy in new building processes. These characterize the constructive and technological systems by innovative components and materials.

Then an advanced building industry production by curtain walls read, efficienty ventilated walls, double or triple glazed skin (suitably exposed to the south), fixed or mobile shading devices, with sensors, etc., use of environmentally friendly materials and certified. All systems are targeting energy efficiency, hermetically isolating the envelope with a continuous sealing layers, heat recovery with heat exchange and continuous ventilation (exclusion of dust and pollen from the air), achieving excellent levels of thermal insulation, excluding thermal bridges in the structure, etc. Directives aim primarily to energy efficiency in operation costs, indoor climate conditions in buildings, local conditions, close to the potential use of renewable energy sources for $\mathrm{CO}_{2}$ reduction. The example is the nZEB (Nearly Zero Energy Building) designed by architects P. Samyn and Partners for ACG offices. An efficient and sustainable building with an architectural design that integrates passive solar systems and renewable energy sources, with open space that illuminate the interior offices (Fig. 6), is equipped with maximum comfort for the users, especially of benefit light. Among the solar technologies efficient are highlighted in double skin glass facades: external, internal layer, with glass energy-efficient system with extra-super-insulation coating treatment and solar control (thermobel top + on clearvision), with dynamic shielding screen-printed glass. These are solutions that combine the function of heat insulation to the integrated design principles through a high color rendering for aesthetics with brightness and integration into the landscape. The patio inner skin is made of Thermobel Energy on Clearvision with external facing of modular panels of wood, made up of compressed bamboo fibers. This type of heat treated wood, ensures high durability class according to EN standards, ENV (Environment) EU and has also been adopted in the walking surfaces and furniture design. Energy systems, integrated from renewable sources, stand out with photovoltaic

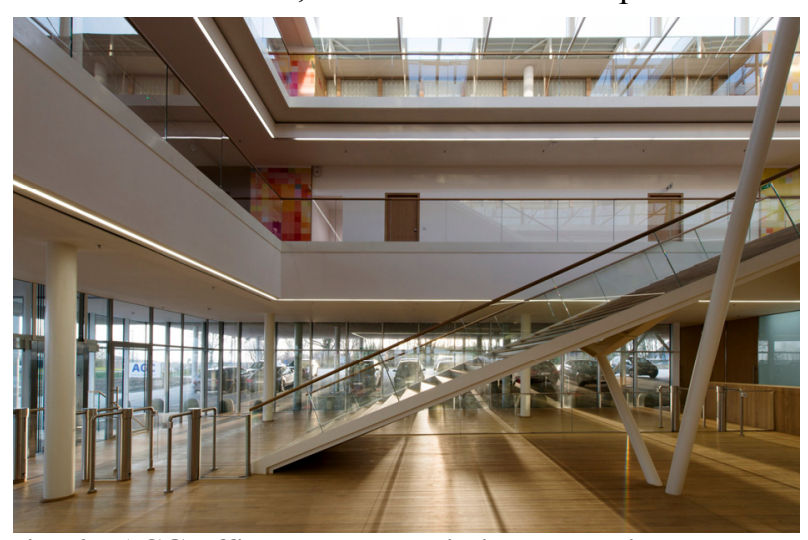

Fig. 6 ACG offices-nZEB Building, Louvain La Neuve, Belgium (interior perspective).

Source: Ref. [11]. 
technology on the roof, with 900 panels, heat pumps and use of geothermal energy. The building has been certified Breem in 2014.

The NREL (National Renewable Energy Laboratory) in a recent May 2016 report shows that the ITC (Incentive Tax Credit) from $30 \%$ to $26 \%$ will pass in 2020. So costs with the integration of renewable sources in architecture design where PV is the driving force for the new configurations in the constructions. Even the type of PV connetted-grid is a global energy and benefits the building through installation with quality control, rooftop (south, east/west) and in front, without batteries, thus reducing air pollution rate. Instead, PV technology stand-alone, off-grid, self-employed, is applied in envelopes where it requires supply to remote areas or of substantial supply need not served by the national grid. Both produce electricity from solar energy which is produced by electromagnetic energy that results from the merger of Hydrogen present in the sun. With the photovoltaic cogeneration, a part of solar energy, not converted into electricity, is recovered and used in thermal, compared to that converted ranging between $6 \%$ to $15 \%$. The recovery takes place with the daylighting of transparent photovoltaic cells, with ventilated photovoltaic modules on one side and with CPVT (Hybrid Concentrating Photovoltaic and Thermal) hybrid systems.

With the type of hybrid photovoltaic projecting a new market FV (Photovoltaic) which can store energy, in the absence of solar hours, and during the night by supplying energy both in large buildings, hospitals, offices, etc. or an enterprise, the trend is to maximize the productivity of these systems, to prevent the rise of energy consumption, since the incentives in Italy were eliminated as also occurred in Germany and England.

Excellent quality photovoltaic technologies also represent a high-performance architectural envelope, and have a low impact on both the building and the environment.

The trend is the integration of these technologies in architectural design, which integrated supply of form and function with efficiency and performance outcomes in the building, thermal/visual comfort in buildings with high indoor air quality. Within it, the new process of integration and energetic configuration, especially in photovoltaic (b), are distinguished for different geographic location and how to install. As in BIPV buildings in the Eur district of Rome of New Congress Center, a flexible architecture, with curtain

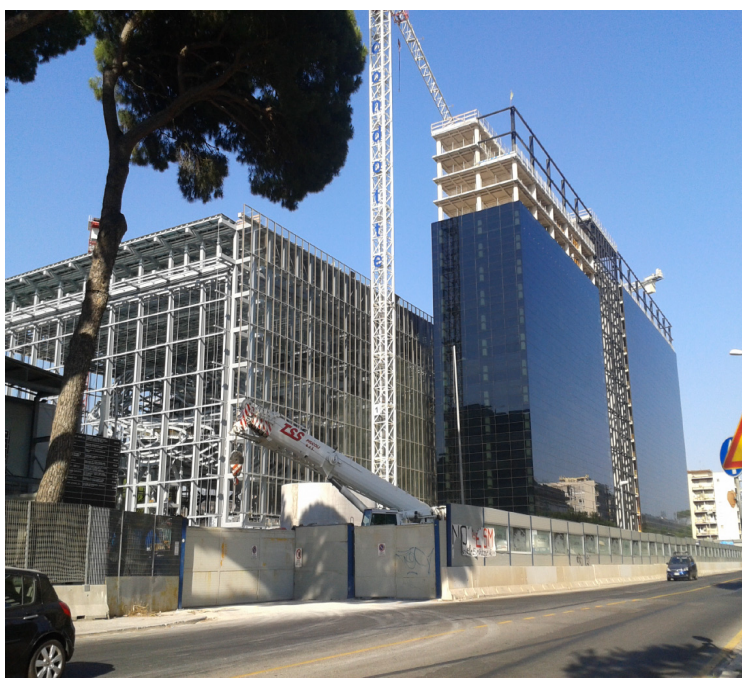

(a)

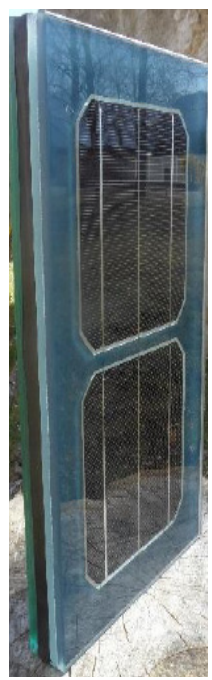

(b)

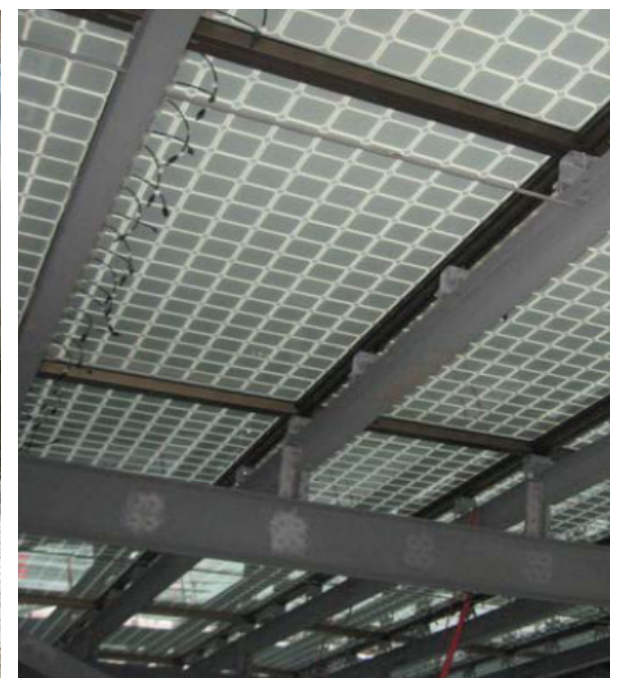

(c)

Fig. 7 New Congress Center, Eur Roma-Italy, project by Arch. Massimiliano Fuksas: (a) perspective; (b) steel structure-detail: cover with PV; (c) double glass PV, panels-264 modules $(3,60 \mathrm{~m} \times 1,60 \mathrm{~m})$ on $1,200 \mathrm{~m}^{2}$ of covering $10,000 \mathrm{~m}^{2}$, per $150 \mathrm{Kwp}$ in total, installed on the cover of the "shrine".

Source: Refs. [12-13], New Congress Center, Eur Roma-Italy, photo (a) by the author (arch. Consiglia Mocerino) of 3 July, 2012. 
wall and a steel construction, designed by the Arch. M. Fuksas (Fig. 7). In the building, which was opened in 2016, different construction technologies are applied. These meet techno/structural/engineering requirements of the building, interacting with the photovoltaic product in the trend of lower cost of investment and efficient ROI (Return on Investment). Especially, for the latter objectives, there are many initiatives in the countries of the world, including the US, which, with the DoE (Department of Energy) through the SunShot Initiative aim, without incentives, to equal the cost of solar sources to those of conventional sources. In general, the photovoltaic modules are integrated in the building with the requirements of flexibility and modularity allowing the possibility to be enhanced or weakened. They are malleable and functional and are configured in the building in relation to their distribution on the façade or roof indicating a low cost of maintenance. A further reduction of energy costs, especially for commercial and residential buildings, maximizing solar energy consumption is achieved through the integration of the photovoltaic system with the ESS (Energy Storage System) with lithium-ion batteries, which can be increased according to the needs and requests that accumulate electricity during off-peak hours. So you get independence from the methane gas network, and from the national grid, to use energy for heating and cooling. To such an extent, the new market shows several techniques an different types of photovoltaic systems.

Further PV and use of efficiency wood coating technologies and ecological material certified far more durable, it stands out in the high efficiency performance architecture "Pushed Slab", designed and built by MRVD (Winy Maas, Jacob Van Rijs, Nathalie De Vries), 2014 . It belongs to urban planning, and is the first sustainability building built in the Parisian neighborhood of the 13th arrondissement. The building of seven floors, spreads over $150 \mathrm{~m} \times 21 \mathrm{~m}$ over an area of $4,150 \mathrm{~m}^{2}$, and is contextualized between the high-density area, close to downtown, and pushed to the south. The building both for offices that residences, supplemented by constructive and energy technologies shows an enclosure covered with FSC (Forest Stewardship Council) certified wood slats (Austrian Larch with layers of grey woodstain-CNF/carbon nanofibers, ecolabel) that reduce the thermal bridges. In addition, there are mobile sun shields along with the rooftop installation of about 264 photovoltaic panels $(90 \mathrm{KW} /$ year of energy) that indicate a reduction in energy demand by about 1/4 compared to traditional buildings. Annually on its energy consumption is $49 \mathrm{kWh}$ per 2.00 sq.m. For about $45 \%$ of the energy demand for DHW heating, 22 solar collectors are installed on the roof. The building "Pushed Slab" (Fig. 8), has obtained the label Ranking Effinergie BBC/Bâtiment Basse Consommation, accordance objectives set out in the "Plan Climat de la ville de Paris".

In third-generation PV, compared to the silicon structure, mono or poly-crystalline photovoltaic cells are the polymeric thin film cell with a potential of innovative semiconductors and nanostructured materials to which they belong:

- DSSC (Dye Sensitized Solar Cell), including that in the solid state, and are cells of cadmium telluride (CdTe) with an efficiency of over $20 \%$ and $17.5 \%$ of the module;

- OPV (Organic Photovoltaic) of organic ultra-thin film (PET-Polyethylene Terephthalate-for the recycling of materials) that is used in amounts of about 100 times lower than those in crystalline modules glass;

- Perovskite cells (Fig. 9) to energy efficiency, which are produced on $3 \mathrm{D}$ printers films and require less light, while presenting easy moisture problems and risk of rupture with lead spill. For this purpose, the search is towards a "spray" technology with ink to graphene sprayed on a transparent surface, that fits in the future to replace the windows of a building efficient. The Silicene with superb optical, chemical and 


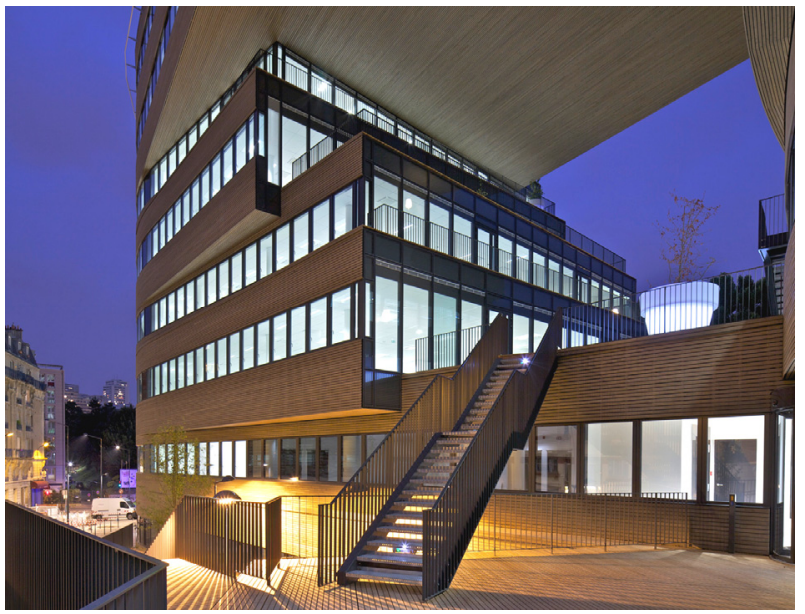

Fig. 8 Pushed Slab/MVRDV, Paris (perspective). Glass envelope with wooden cladding of certified Austrian larch. Source: Ref. [14].

electronic properties is an innovative material that could exceed the performance of graphene on the low cost and thin size, according to a recent study in Germany in the Technical University of Berlin, University of Aix/Marseille in France in collaboration with Italian CNR (National Research Council). In Barkeley Lab, in California, recent research indicates that the surface of solar cells peroskite (Fig. 9), which generates a higher photovoltaic efficiencies. It, detected in grain of 200 nanometers, with growth potential, is delineated by facets in black color, in which the green color represents high performance, while red indicates a low performance;

- QD (Quantum Dot) PV, high absorption nanoparticles. The organic/inorganic hybrid PV cells also have high-performance, highly integrated architecture. The innovations are the cells to the polymer of ultra-thin thickness of less than a micrometer to about 180 micrometers of silicon solar panels. The disadvantage is to denounce low efficiency values $(10.6 \%)$ due to weather and climatic excursions. The objective is also the third generation photovoltaic, research through excitonic solar cells, dye sensitized and nanostructured hybrid solar cells.

The integration of this PV technology is highlighted by buildings integrated BIPV where efficient energy modules, become wrapper façade elements and multi-functional coverage, and to reduce the energy demand for heating and cooling. In addition, the PV is applied in shading and fall protection systems, for which, it is necessary to distinguish the shape, the size, the techno/special design and color, in a single project of aesthetics/function/systems. Another exemplary is in the city of Frankfurt (Germany) where a residential building BIPV was built, high-energy performances, Aktiv-Stadthaus HHS Planer + Architekten AG (Fig. 10). The mainly goals are efficiency, sustainability, strategy energy, life cycle approach, for example, with the use of photovoltaics that produce

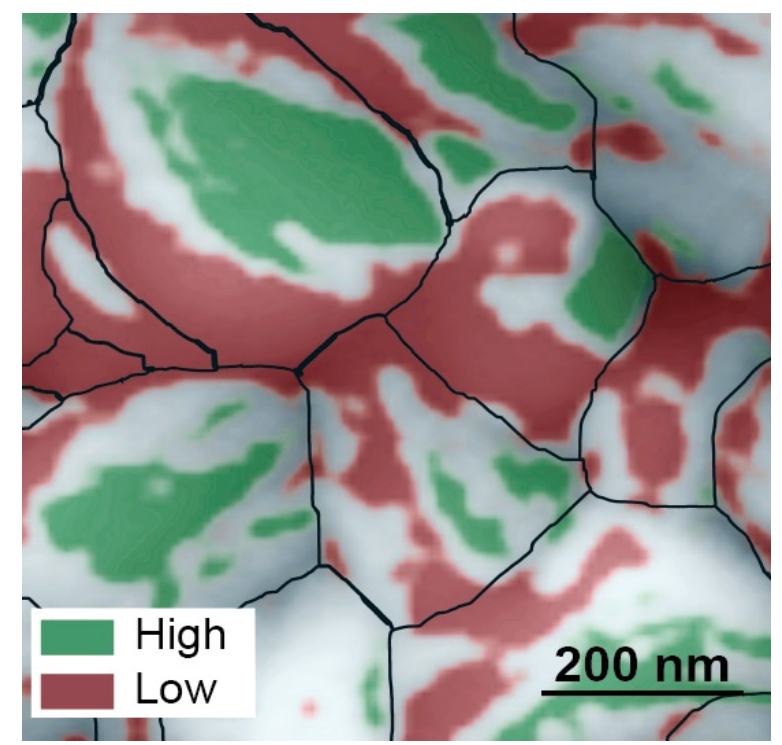

Fig. 9 Perovskite solar cells-potential photovoltaic efficiency: red (high performance), green (low performance) .

Source: Ref. [15].

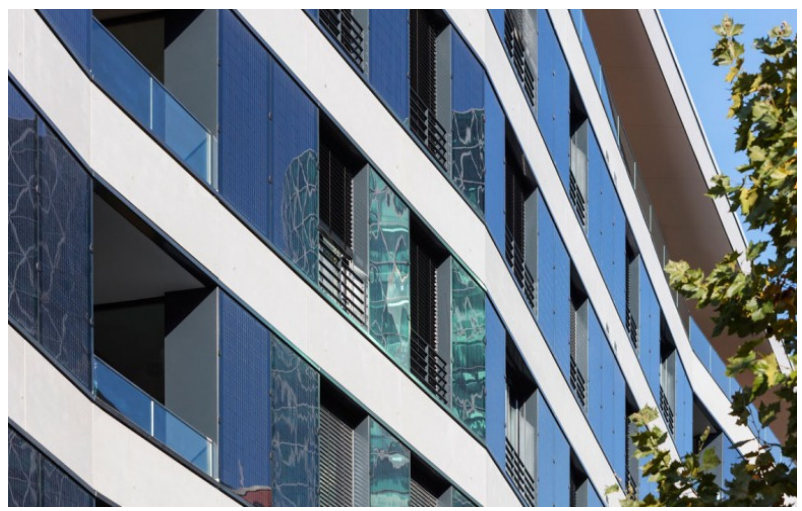

Fig. 10 Aktiv-Stadthaus by HHS Planer + Architects AG-south Façade: PV integrated in eternit fiber cement. Source: Ref. [16]. 


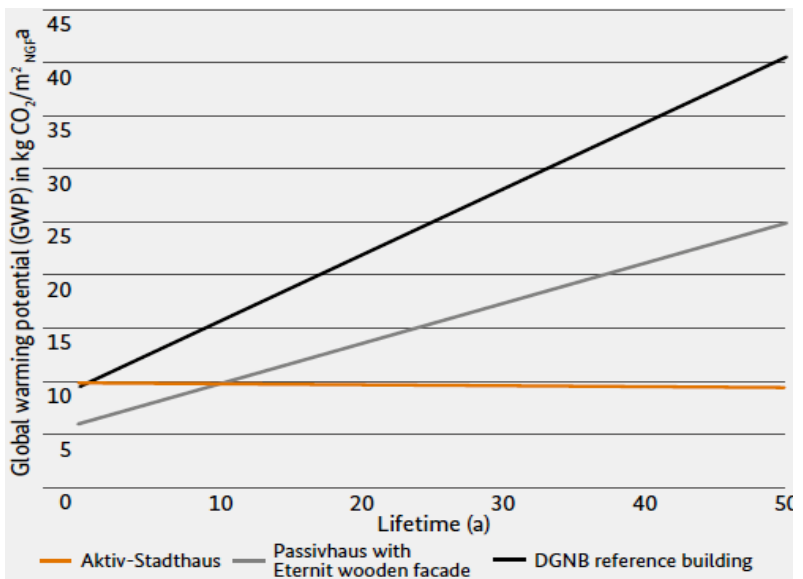

Fig. 11 Aktiv-Stadthaus by HHS Planer + Architects AG: comparison with passive house and DGNB (Deutsche Gesellschaft für Nachhaltiges Bauen) buildings (the same type of construction): GWP (Global Warming Potential). Source: Ref. [17].

energy surplus, energy management for user (Fig. 11) by an efficiency interface system of new generation technology of electricity. It is identified in the energy policies of BMVBS (Bundesministerium für Verkehr, Bau und Stadtentwicklung) in which primarily highlights the use photovoltaic modules, energy and renewable in situ as the use of geothermal renewable energy, heat pumps and heat exchangers. On the roof, they have been installed $770 \mathrm{PV}$ conventional modules high-performance. While on the south façade, 348 BIPV panels are integrated in the concrete parapets whose height is $50 \mathrm{~cm}$ with eternit fiber cement, the type Equitone-tectiva. On all sides of the façade, there is a value of $\mathrm{Ua}$ (U-value) of $0.129 \mathrm{~W} / \mathrm{m}^{2} \mathrm{~K}$ with a wood element façade. The surface maximization through 17 loggias and overall costs $€ 277,597$. In it, they have installed BMS (Building Management System), PV panels that produce the electricity surplus and transferred (almost 50\%) to urban network, through an electricity storage system, also, there are inverters. It comes with decentralized ventilation with heat recovery.

Definitely, there are many initiatives and research including the EC-Horizon 2020, the Seventh European program that arise from technological innovation objectives in a ratio of cost/efficiency. In the types of cells with a microamorphous thin layer of film applied on glass microamorphous cells and taken on the roofs or in the skin of the building as ventilated facades, it can reach high performance in addition to $8.5 \%$ more electricity. The electrical cables of a semi-transparent PV module protrude laterally in the frame or through the junction box, while two glass plates are glued by resin with a gap of $2 \mathrm{~mm}$. To achieve the thermal transmittance values of $1.1 \mathrm{~W} / \mathrm{mqK}$ for thermal insulation adds a double glass module, the quality standard of IP65 certifies the absence of water and moisture penetration.

\section{Conclusions}

The climatic variations and not very coordinated management of political transformations and implementation of programs for use of renewable energy resources, were transferred to growing environmental problems. In fact, the slow and not enough meaningful use of interventions decarbonisation turns to the increase in atmospheric pollution levels of $\mathrm{CO}_{2}$ with percentages, the point of no return. Unfortunately, the buildings with all the infrastructure still indicate a high rate of pollution that has a significant effect, for which it needs, first of all, the reduction in this percentage by making good use of renewable energies. For these objectives, it requires integrated planning of an evolutionary method in which the BIM, ICT, building automation and BIot, interacting in a meta-system aimed at a meta-project of architecture, structure and systems for high control of energy consumption and reduction of pollution. So the integration of energy technologies with the relaunch of building technologies in the new settlement culture by methodologies differ in new building process models and product, with by quality certifications, according to world standards. Then through the building, space and business management, they are projected in construction management. The integrated design intended for a multidisciplinary project team of designers for the realization of efficient and more 
secure buildings, with reducing both risk and construction defects, visual and thermal comfort. The interface with digital high performance devices, installed in efficient buildings, favors the monitoring energy consumption and indoor air quality, and highlight dynamic envelopes double- or triple-glazed skin with intelligent shading systems and new technologies. Among the regulatory/techno/scientific instruments will highlight the applications of various construction and energy systems and innovative technologies that integrate the construction in progress of emerging economies. So production of, photovoltaic solar panels glazed, the ultra thin film cell, nanostructured (Dye Sensitized Solar Cell, Organic Photovoltaic, Perovskite Cells, Quantum Dot-PV), BIPV buildings, with solar cogeneration, etc. The surplus energy produced by the photovoltaic is transmitted to a network of smart grid, through digital technologies, in function of the large expansion of the distributed generation of electrical energy and it represents the potential towards a sustainable transition to renewable energy. In this perspective, the need for a new culture for constructive processes with high performance component systems is added, innovative materials integrated to new and secure technology and energy systems, giving stability against any risk of natural, seismic, hydrogeological, erosion, etc. The buildings must be integrated with clean energy technologies, and they must put in the context zero impact with constructive and housing high-quality.

\section{References}

[1] The Guardian. 2016. Keep Fossil Fuels in the Ground to Stop Climate Change. Accessed June 10, 2016. https://www.theguardian.com/environment/2015/mar/10/k eep- fossil-fuels-in-the-ground-to-stop-climate-change.

[2] EU. 2014. Azione per il clima-Europa. Accessed August 21, 2016. https://europa.eu/europeanunion/file/755/down load_it?token=4BtNK2Xy.

[3] IEA. 2016. "Energy Technology Perspectives: Towards Sustainable Urban Energy.” Accessed September 1, 2016. https://www.iea.org/.../etp/etp2016/ETP2016_Webinar_A LL.pdf.
[4] Schneegans, J., Klimbe, K., and Riemer, H., Technische Universität München (TUM). 2014. Using Buildings to Store Electricity. Zukunft Bauen-Forschungsinitiative Zukunft Bau. Accessed August 3, 2016 www.forschungsinitiative.de/..._00_Zukunft_Bau_2014_ e.pdf.

[5] Viticoli, S., and Ambrosio, L. 2014. Le Key Enabling Technologies, Un'occasione per la Competitività del Sistema Industriale Italiano. Airi (Associazione Italiana per la Ricerca Industriale)-Ed. Milano: Guerini e Associati.

[6] Weller, B., Fahrion, M.-S., Horn, S., Naumann, T., and Nikolowski, J. 2016. Baukonstruktion im Klimawandel. New York: Ed. Springer Vieweg.

[7] MIT. 2016. New Solar Cell Is More Efficient, Costs Less than Its Counterparts. MIT News Office. Accessed September 5, 2016. http://news.mit.edu/2016/new-solarcell-more-efficient-costs-less-its-counterparts-0829.

[8] Weller, B., Marc-Steffen, F., Horn, S., and Fischer, J., Opaque Facade Panels with Integrated Photovoltaic. Zukunft Bauen-Forschungsinitiative Zukunft Bau . TU Dresden. Accessed September 3, 2016 www.forschungs initiative.de/.../00_Zukunft_Bau_2014e.pdf.

[9] Mocerino, C. 2015. "Modello Edilizio nell' Innovazione di Processo Progettuale per il Recupero e la Riqualificazione Dell'Edilizia Terziaria. Linee Guida Prestazionali." Ph.D. thesis, Sapienza University of Rome. Accessed September 10, 2016. http://padis.uniroma1. it/handle/10805/2766.

[10] Nordby, A. S., and Jørgensen, P. F. 2016. Guida alla Progettazione Integrata. MaTrID Project Ec. Accessed August 18, 2016 http://www.integrateddesign.eu/down loads/D.4.3.A.1_Guida-alla-Progettazione-Integrata_ITA REV2.pdf.

[11] Head Office of AGC Glass Europe/SAMYN and PARTNERS. 2016. Foto by Marie-Françoise Plissart. Accessed September 8, 2016, http://www.archdaily.com/ 644709/head-office-of-agc-glass-europe-samyn-andpartn ers/5584bfdbe58ece1737000192-head-office-of-agc-glass -europe-samyn-and-partners-photo.

[12] Officine Tosoni Lino SpA. 2016. Centro Congressi "La Nuvola”. Accessed September 3, 2016 www.officineto soni.com/media//cordioli/progetti/EUR_09_bbr.pdf.

[13] New Congress Center, Eur Roma-Italy. 2016. Detail Photovoltaic Module. FAR System, Building Integrated Photovoltaic. Accessed July 24, 2016. www.farsystems.it.

[14] Pushed Slab/MVRDV, foto by Philippe Ruault. Accessed September 2, 2016. http://www.archdaily.com/572616 /pushed-slabmvrdv/54766d16e58ece540e0001ba-05_-cphilippe_ruault-jpg.

[15] News Center-Barkeley Lab by the University of 
California. 2016. "Possible Secret to More Efficient Perovskite Solar Cells." Accessed August 30, 2016. http://newscenter.lbl.gov/2016/07/04/perovskite-solar-cel ls/.

[16] Referenz Eternit. 2016. Aktiv Stadthaus. Frankfurt. Foto by Constantin Meyer. Accessed September 3, 2016. www.eternit.de/referenzen/aktiv-stadthaus-frankfur.

[17] Hegger, M., and Kassel, H. S. S. 2014. Aktiv-Stadthaus. The First plus-energy apartment building in a city centre. Zukunft Bauen. Zukunft Bau Research Initiative 2014. Accessed July 20, 2016. www.forschungsinitiative.de /..._00_Zukunft_Bau_2014_e.pdf. 